\title{
STATISTICAL ANALYSIS OF THE MAIN TRENDS IN THE DEVELOPMENT OF INDUSTRIAL SECTORS OF THE REPUBLIC OF KARAKALPAKSTAN
}

\author{
Sariev Qahromon Ramatullaevich \\ Independent researcher of the Department of Economics, Karakalpak State University, Uzbekistan
}

ABSTRACT

DOI No: $10.36713 /$ epra8331

Article DOI URL: https://doi.org/10.36713/epra8331

In this article, the role of the industrial network in the national economy, its sustainable development in the Republic of Karakalpakstan, innovative activity of the network and the effectiveness of management are highlighted.

KEYWORDS: GDP, industrial sectors, industrial production, business, small business, competitiveness, competitiveness, restructuring, management, national economy, small business shares, innovation activity

\section{INTRODUCTION}

The share of industrial production in GDP has been steadily increasing in recent years through the development of existing industries and sectors of industry, the formation of new industries with sufficient resource potential.

The growth of industrial production means an increase in the funds and resources of enterprises in the sector. The government's policy of reducing the tax burden, liberalizing fiscal policy, simplifying the taxation system, ensuring targeted and long-term sustainable development has led to an increase in GDP and an increase in the share of industrial production.

The effectiveness of programs designed to increase the share of small business and private entrepreneurship in the economy and the growth of demand for industrial products in the world market, including food, light and machinery industries, will ultimately lead to additional growth of industrial production. brought.

If we pay attention to the structure of industrial production, we can see that in the past period of independence, the fuel and energy, metallurgy, machinery and metal processing industries have been growing rapidly.

The dynamics of the indicators of the industrial sector in the Republic of Karakalpakstan for the last 5 years (2015-2019) more clearly shows the rapid development of the regional industrial sector in the period under review (Table 1). 
Table 1

Dynamics of indicators representing the industrial sector of the Republic of Karakalpakstan (in current prices)

\begin{tabular}{|c|c|c|c|c|c|c|c|}
\hline \multirow{2}{*}{ № } & \multirow{2}{*}{ Indicators } & \multicolumn{5}{|c|}{ Years } & \multirow{2}{*}{$\begin{array}{l}\text { Changes in } \\
2019 \\
\text { compared } \\
\text { to } 2015 \%\end{array}$} \\
\hline & & 2015 & 2016 & 2017 & 2018 & 2019 & \\
\hline \multirow[b]{2}{*}{1.} & $\begin{array}{l}\text { The volume of industrial } \\
\text { output, in current prices, } \\
\text { amounted to billions of soums }\end{array}$ & 2387,6 & 4265,7 & 6773,3 & 10911,9 & 12736,1 & 5,3 м. \\
\hline & including: & $\begin{array}{c}136,4 \\
1778,6\end{array}$ & $\begin{array}{c}169,7 \\
3614,8\end{array}$ & $\begin{array}{c}234,7 \\
6040,3\end{array}$ & $\begin{array}{c}356,7 \\
9838,8\end{array}$ & $\begin{array}{c}503,6 \\
11023,7\end{array}$ & $\begin{array}{l}3,7 \mathrm{M} . \\
6,2 \mathrm{M.}\end{array}$ \\
\hline 2. & - mining industry & 139,1 & 178,7 & 158,8 & 161,1 & 116,7 & $-22,4$ \\
\hline 3. & - processing industry & 2,4 & 3,8 & 4,5 & 4,6 & 3,9 & $+1,5$ \\
\hline 4. & $\begin{array}{l}\text { Growth rate of industrial } \\
\text { production, } \%\end{array}$ & 93 & 96 & 102 & 104 & 107 & 115,1 \\
\hline 5. & $\begin{array}{l}\text { The share of industrial } \\
\text { production in relation to the } \\
\text { Republic, } \%\end{array}$ & 1064 & 1031 & 1282 & 1621 & 1783 & 167,5 \\
\hline 6. & $\begin{array}{l}\text { Number of mining } \\
\text { enterprises, units }\end{array}$ & 7 & 8 & 5 & 6 & 8 & 114,3 \\
\hline 7. & $\begin{array}{l}\text { Number of processing } \\
\text { enterprises, units }\end{array}$ & 142,2 & 1018,4 & 2303,3 & 3952,7 & 5284,2 & 37,2 м. \\
\hline 8. & $\begin{array}{l}\text { Number of projects } \\
\text { implemented under the } \\
\text { localization program, units }\end{array}$ & 1343,5 & 2364,2 & 3701,4 & 5879,3 & 6759,8 & 5,0 м. \\
\hline 9. & $\begin{array}{l}\text { The volume of industrial } \\
\text { products produced on the } \\
\text { basis of the localization } \\
\text { program, billion soums }\end{array}$ & 136,9 & 176,0 & 156,5 & 158,8 & 115,0 & $-21,9$ \\
\hline 10. & $\begin{array}{l}\text { Volume of industrial products } \\
\text { per capita, thousand soums }\end{array}$ & 121,3 & 165,2 & 110,4 & 107,4 & 118,3 & $-3,0$ \\
\hline 11. & $\begin{array}{l}\text { Per capita industrial output } \\
\text { growth rate, } \%\end{array}$ & 59,8 & 60,9 & 61,3 & 60,6 & 63,4 & 106,0 \\
\hline 12. & $\begin{array}{l}\text { Growth rate of labor } \\
\text { productivity in industry } \\
\text { (compared to last year),\% }\end{array}$ & 1393,0 & 3528,2 & 6061,5 & 10002,4 & 11957,3 & 8,6 м. \\
\hline
\end{tabular}

During the period under review, the volume of regional industrial output increased by 5.3 times in total, including mining by 3.7 times and processing by 6.2 times. During these years, the highest growth rate compared to the previous year was in 2016 , which was $178.7 \%$ compared to 2015 .

The analysis of the table data shows that the main part of the development indicators of the region's industrial sectors has grown rapidly in recent years, the level of industrialization of the economy in a very underdeveloped region is deliberately approaching the level of other regions of the country.

Sectoral analysis of industrial production in the Republic of Karakalpakstan provides a clearer picture of changes in the volume of industrial production in the region on the basis of sectoral changes (Table 2). 
Table 2

The dynamics of the industry structure of the volume of industrial output in the Republic of Karakalpakstan, billion soums

\begin{tabular}{|c|c|c|c|c|c|c|c|c|c|}
\hline \multirow[t]{2}{*}{ Industries } & \multicolumn{8}{|c|}{ Years } & \multirow{2}{*}{ 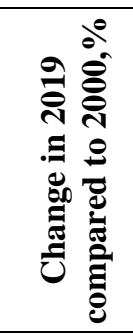 } \\
\hline & 2000 & 2005 & 2010 & 2015 & 2016 & 2017 & 2018 & 2019 & \\
\hline Regional industrial output & 44,16 & 198,8 & 697,2 & 2387,6 & 4265,7 & 6773,3 & 10911,9 & 12736,1 & $288,4 \mathrm{M}$. \\
\hline$\%$ & 100 & 100 & 100 & 100 & 100 & 100 & 100 & 100 & - \\
\hline \multicolumn{10}{|l|}{ including: } \\
\hline food industry & 13,05 & 37,2 & 169,1 & 827,2 & 925 & 1010,1 & 1308,1 & 1730,5 & $132,6 \mathrm{m.}$ \\
\hline$\%$ & 29,6 & 18,7 & 24,3 & 34,6 & 21,7 & 14,9 & 12,0 & 13,6 & $-16,0$ \\
\hline metallurgical industry & - & - & - & 0,5 & 0,4 & 0,7 & 0,5 & 1,9 & $38,0 \mathrm{м.}$ \\
\hline$\%$ & - & - & - & 0,02 & 0,01 & 0,01 & 0,01 & 0,01 & $-0,01$ \\
\hline chemical industry & 0,04 & 0,4 & 35,4 & 343,2 & 2001,3 & 4062,2 & 6836,2 & 7297,2 & $206,1 \mathrm{м}$. \\
\hline$\%$ & 0,1 & 0,2 & 5,1 & 14,4 & 46,9 & 60,0 & 62,6 & 57,3 & 57,2 \\
\hline machinery industry & 2,22 & 1,5 & 3,9 & 17,6 & 28,4 & 18,7 & 276,6 & 260,7 & $117,4 \mathrm{~m}$. \\
\hline$\%$ & 5,0 & 0,8 & 0,6 & 0,7 & 0,7 & 0,3 & 2,5 & 2,0 & $-3,0$ \\
\hline light industry & 11,38 & 69,8 & 196,7 & 442,7 & 520,9 & 668,5 & 882,5 & 1064,7 & 93,5 м. \\
\hline$\%$ & 25,8 & 35,1 & 28,2 & 18,5 & 12,2 & 9,9 & 8,1 & 8,4 & $-17,4$ \\
\hline energy industry & 9,67 & 50,6 & 178 & 434,3 & 441,5 & 446,8 & 596,1 & 1090,9 & $112,8 \mathrm{~m}$. \\
\hline$\%$ & 21,9 & 25,5 & 25,5 & 18,2 & 10,4 & 6,6 & 5,5 & 8,6 & $-13,3$ \\
\hline mining industry & 2,35 & 24 & 62,4 & 136,4 & 169,7 & 234,7 & 356,7 & 465,6 & $198,1 \mathrm{M.}$. \\
\hline$\%$ & 5,3 & 12,1 & 9,0 & 5,7 & 4,0 & 3,5 & 3,3 & 3,7 & $-1,6$ \\
\hline $\begin{array}{l}\text { building materials } \\
\text { industry }\end{array}$ & 4,03 & 5,9 & 18,9 & 125,6 & 114,9 & 217,6 & 413,3 & 563,3 & 139,8 м. \\
\hline$\%$ & 9,1 & 3,0 & 2,7 & 5,3 & 2,7 & 3,2 & 3,8 & 4,4 & $-4,7$ \\
\hline other industries & 1,42 & 9,4 & 32,8 & 60,1 & 63,6 & 114 & 241,9 & 261,3 & $184,0 \mathrm{м}$. \\
\hline$\%$ & 3,2 & 4,7 & 4,7 & 2,5 & 1,5 & 1,7 & 2,2 & 2,1 & $-1,1$ \\
\hline
\end{tabular}

The analysis of the volume of regional industrial output by industry shows that over the past 19 years, the main industries in the region have over time been replaced by relatively dominant and fastgrowing industries. In particular, in 2000, the food industry, which has a high share in the gross regional product $(29.6 \%)$, light industry $(25.8 \%)$, energy industry $(21.9 \%)$, construction materials industry $(9.1 \%)$ The share of such industries in the volume of regional industrial output decreased by 2019 due to the rapid development of the chemical industry (57.2\% of gross regional industrial output).

This situation is explained by the launch of the Kungrad soda plant in the Republic of Karakalpakstan, the allocation of large investments, special attention is paid to the modernization and diversification of the industry.

Along with the above, it should be noted that the chemical industry, which has a relative advantage in terms of resources, has dramatically changed the structure of industrial production in the region due to its rapid development, even if the regional industries have steadily increased their production.

One of the most pressing issues today is the study of the peculiarities of the formation and development of economic sectors in the process of structural changes in the country, the impact of the development of new, promising sectors of the economy on the social status of the population. Studying the state of development, achieving sustainable development of the regions through effective and optimal use of the existing potential of the regions, achieving priority employment, ensuring the rational use of all available resources - these are the priorities in economic development.

The main factors of industrial development in the country in the past are: "Implementation of targeted programs; formation of infrastructure (water, 
gas, electricity, transport, etc.); establishment of new enterprises in the light industry and development of finished products; establishment of new enterprises in the field of processing of agricultural products and supply of the market with local products; production of consumer goods and their full supply to the market; development of the construction materials industry; increase the effectiveness of bank loans in the development of industry; increasing the share of joint ventures in the development of industry; processing of local raw materials; extensive use of privileges and preferences created within the localization program and the International Industrial Fair and Cooperation Exchange; expanding the volume of exports of manufactured products, assisting in the export of small businesses.

The territory of the Republic of Karakalpakstan consists of 1 city (Nukus) and 16 districts according to the administrative-territorial division, and according to the natural-climatic conditions and resource potential, various spheres of economic activity are developed in these territorial units (Table 3).

Table 3

Changes in the volume of industrial production in the regions of the Republic of Karakalpakstan in 20102019, in percent

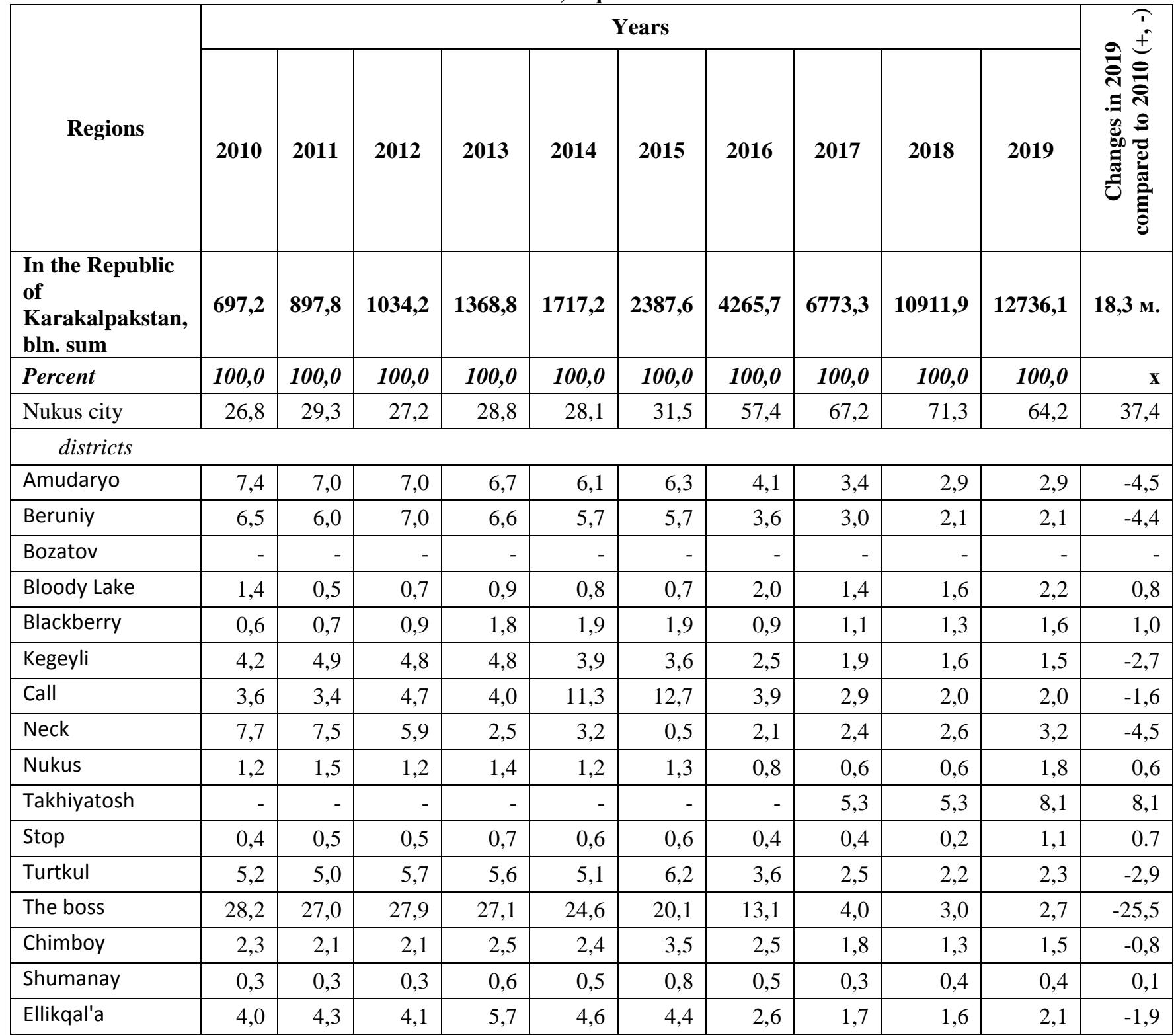

The regional analysis of industrial production in the Republic of Karakalpakstan shows that most of the regions of the republic (except for the city of Nukus, Moynak, Takhiyatash and Khojayli) are industrially undeveloped. The table shows that in Nukus, the regional center of the country, as a result of the centralization of industrial enterprises in 2010 produced $26.8 \%$ of regional industrial output, in 2019 
this figure increased by $37.4 \%$ to $64.2 \%$. With the sharp increase in the number of industrial enterprises located in the city of Nukus and the share of their output in the regional industrial output, industrial production is accompanied by a decrease in the share of Moynak and Khojayli districts in this indicator.

In general, the analysis of changes in the volume of industrial production in the regions Amudarya (-4.5\%), Beruni (-4.4\%), Kegeyli (-2.7\%), Moynak (-4.5\%), Turtkul $(-2,9 \%)$ and Khojayli districts, and Nukus city (37.4\%), Kanlikul (0.8\%), Karaozak (1.0\%), Nukus (0.6\%), Takhiyatash $(8.1 \%) . \%)$, Takhtakor $(0.7 \%)$ and Shumanay $(0.1 \%)$ districts.

The volume of industrial output per capita, as shown in Table 4, is higher in Nukus than in other regions, but on average 7-10 times higher than in other regions, except Muynak and Takhiyatash districts. In Muynak and Takhiyatash districts, the figure was about 2 times lower than in Nukus, but on average 4-5 times higher than in other regions.

From the data in the table above, it can be concluded that in a few regions of the country (Nukus, Moynak, Takhiyatash, Kanlikul and Nukus districts) the development of industrial sectors has been growing steadily, with significant changes.

Based on the above analysis and the trends identified on their basis, we consider it appropriate to implement industrial production in the country in the following areas:

To develop sectoral programs for industrial modernization, including the introduction of financial and non-financial mechanisms to stimulate the demand of enterprises for modern technologies, increase the global competitiveness of the national economy, create conditions for a gradual transition to innovation and knowledge economy, and improve living standards and quality We consider it expedient to take into account the following:

- Ensuring the introduction of measures and requirements for the gradual decommissioning of obsolete equipment in the development of modernization and technical re-equipment programs;

- It is necessary to conduct an inventory of obsolete equipment and technological lines at enterprises and monitor their gradual release;

- Ensuring the introduction of new equipment and technical equipment in the production activities of the enterprise for a certain period of time in terms of value and taking into account the continuity and consistency of technological processes of equipment;

- pay special attention to the task of expanding the range of products and services;

- It is necessary to ensure the maintenance of optimal ratios in the fixed assets of the enterprise.

\section{REFERENCES}

1. Komarova O.V. Problems of the development of handicrafts, small and medium business and the middle class: monograph // O.V. Komarova, T.A. Salamatova, D.E. Gavrilov. -Yekaterinburg: Publishing house Ros. state prof. - ped. University, 2012. $-158 p$.

2. Abdullaev Yo. Basics of Small Business and Entrepreneurship Part 1100 questions and 100 answers. $-T$.: Mehnat, 2000. -311 p.

3. Shodiev H., Hamroev M. Financial Statistics / Textbook - T .: Abu Ali Ibn Sino Medical Publishing House, 2002. -216 p.

4. Course sotcial-economical statistics; under the editorship of Doctor of Economic Sciences, Professor M.G. Nazarova.-, 2000. -311 p.

5. United States Small Business Profile 2020. SBA, 2020, pp. 7-8.

6. Data of the State Statistics Committee of the Republic of Uzbekistan. www.stat.uz

7. www.kitobxon.uz

8. www.lex.uz 